\title{
Multiple Literacies, Curriculum, and Instruction in Early Childhood and Elementary School
}

This article describes some implications of using a multiple literacies perspective in the construction and implementation of literacy curriculum, pedagogy, and assessment in early childhood and elementary classrooms. After briefly laying out a theoretical perspective in sections focusing on early literacy, academic learning, literacy beyond schools, literacy and social justice, and assessment, the article grounds the theoretical claims in examples of classroom practice. The article closes with the argument that by shifting the focus of the teaching and learning of literacy from an autonomous model to include a multiple literacies perspective, we can construct authentic spaces for learning that prepare students for equitable par-

Joanne Larson is Professor and Chair in the Warner Graduate School of Education and Human Development at the University of Rochester.

Correspondence should be addressed to Joanne Larson, Warner Graduate School of Education and Human Development, Dewey Hall 1-160E, University of Rochester, Rochester, NY 14627. E-mail: Joanne.larson@ rochester.edu ticipation in a global communication and information economy.

I N THIS ARTICLE, I describe some implications of using a multiple literacies perspective in the construction and implementation of literacy curriculum in early childhood and elementary classrooms. After briefly laying out a theoretical perspective in sections focusing on early literacy, academic learning, literacy beyond schools, literacy and social justice, and assessment, I ground the theoretical claims in examples of classroom practice. My argument is that a multiple literacies perspective is a meaningful position from which education can remain relevant in contemporary society. If schools continue a singular focus on traditional conceptions of literacy as autonomous skills (e.g., viewing language and literacy as "parts" that can be used independent of context, audience, and purpose; cf., Street, 1995), they will be in danger of becoming irrelevant to the construction of meaningful life pathways (Lankshear 
\& Knobel, 2003). Schools need to respond to rapidly changing literacy demands of the global economy to allow for adequate preparation in the practices needed for authentic participation. A multiple literacies perspective offers schools tools to do so.

\section{Multiple Literacies and Early Literacy Curriculum and Instruction}

Research on language and literacy acquisition and development has documented how young children learn to use language through authentic participation in the language practices of their communities (Heath, 1983; Ochs, 1988). Research in literacy studies has built on this work to understand how the language and literacy practices of everyday life, professions, and institutions (including schools and classrooms) contribute to language and literacy development across the life span (Barton \& Hamilton, 1998; Dyson, 1993, 2002; Freire, 1972; Kress, 1997, 2003; Luke, 1994; Marsh, 2003; Street, 1995, 2005). This body of work lets researchers and teachers know that language is the medium of instruction and that how language is used shapes what gets learned, how it is learned, and who gets to learn it. Research using multidisciplinary perspectives has further developed what we know about early language and literacy practices through detailed analysis of literacies in use, particularly in classrooms (Bloome, Carter, Christian, Otto, \& Shuart-Faris, 2005; Gee, 2004; Green \& Harker, 1988; Hall, Larson, \& Marsh, 2003; Larson \& Marsh, 2005; Street, 2005). From this research, we know that language and literacy learning in the early years is linked to identity as children bring their language abilities, what Gee calls vernacular languages, to bear on a development of a sense of self. In other words, as children are socialized to use schoolbased language, they integrate this new discourse into the language and literacy practices they bring from home-all of which become key processes in their developing identities. Furthermore, understanding how children are socialized to use school-based, or specialist languages (e.g., those discourse practices associated with academic con- tent areas; Gee, 2004) informs the development of classroom practices that facilitate the complex learning demands of academic settings, learning demands that require a multiple literacies perspective that takes into account an ideological model of literacy. I develop this idea further in the following section.

\section{Multiple Literacies and Practices of Academic Learning}

Street (1995) describes a continuum of models that ranges from autonomous to ideological conceptions of literacy. On one end, an autonomous model of literacy is one in which literacy is defined as a set of skills that can be taught similarly across varying contexts (e.g., autonomous of the context of use); it claims to be value-free literacy and, as such, can be applied in analogous ways despite the very different needs and experiences of learners. On the other end, an ideological model of literacy is shaped by particular social, cultural, historical, economic, and political contexts and is always ideological, that is, always carries particular meanings and is imbued with power (Street, 1995; e.g., literacy is situated in the context/s of use). It is generally an autonomous model of literacy that underpins the construction of school curricula and pervades teachers' instructional and assessment practices (Larson \& Marsh, 2005).

Several researchers have documented the consequences of a curriculum that is based solely on an autonomous model of literacy on early childhood and elementary level classrooms. For example, Irvine and Larson (2001) found that an autonomous definition of literacy could be closely aligned with a deficit model of elementary students' abilities, resulting in curricular and academic disadvantage (e.g., students had unequal access to participation in literacy events). Given such a model, teachers chose activities from the textbook series that they felt would remediate what they perceived were deficits in the children's capabilities. They assumed that the definition of literacy presented in the textbook (e.g., an autonomous set of neutral skills) was the correct view. Those findings were consistent with Shannon's 
(1992) research on textbook use. He found that teachers and administrators believed that the textbooks could teach reading and their pedagogical decisions reflected this belief. One consequence of relying exclusively on an autonomous model of literacy is that it precludes attention to the multiple literacies necessary for participating in a complex, global information and communication economy.

What happens when our definition of literacy changes? What would an elementary classroom look like if a multiple literacies perspective (i.e., an ideological definition of literacy) that grounded the curriculum, instruction, and assessment was added to the teacher's repertoires of practices (Gutierrez \& Rogoff, 2003)? A veteran first grade teacher I have worked with, Maryrita Maier, uses her adaptation of a workshop approach to writing instruction to teach academic literacy that is rooted in a multiple literacies view of literacy. She uses this perspective as one way to move her practice toward helping her students understand and use the literacy practices they will use outside of school while still providing them the required academic literacies. In other words, by making her own processes as a writer explicit to her first graders, she offers her students a model of writing in a real context of use that includes the range of models of literacy Street (1995) describes.

She begins her daily writing time with what she calls modeled writing (Larson \& Maier, 2000). She writes a text, typically a personal narrative, on large easel paper as the children watch from their seats on the carpet. She talks through her story and the questions she asks as a writer while the children say what they think she will write next, or offer answers to her questions. She embeds school-based writing lessons in these modeled writing sessions. For example, after carefully examining her students' writing, she might see that some students need additional instruction in paragraphing or punctuation. While one instructional goal then focuses on developing students' competence in punctuation, the larger goal of students writing complex texts that have real audiences and purposes in context remains paramount. This practice of modeling what practices writers use in composing is rooted in a model of literacy that focuses on the socially, culturally, and historically situated practices of composition in academic settings (what Street, 1995, calls an ideological model).

Another elementary teacher I have worked with for many years, Lynn Astarita Gatto, integrates an ideological definition of literacy differently in her classroom (Gatto, 2001; Larson \& Gatto, 2004). While Gatto rejects autonomous definitions of literacy as the sole guide to her curriculum development, she does design her curriculum based on content standards in New York State and her local school district. She anchors her curriculum in extensive units of investigation that integrate all content areas and a multiple literacies perspective. One example is her Urban Botanist Project, in which her students spent the year observing and documenting changes in trees in a local park. After reading biographies of botanists and writing their own biographies, her students learned the literacy practices associated with botany through their trips to the park. They accumulated what they had learned into a multimodal information kiosk they installed at the park, along with pamphlets for visitors to use. After realizing that area teachers rarely visited the park, they put together a teachers' manual that offered suggestions for using the park as a context for learning (Gatto, 2001; Larson, 2005; Larson \& Marsh, 2005). I expand on the implications of her practice of moving outside the classroom in the next section.

Several researchers have documented the growing disconnect between school-based learning and literacy practices and those embedded in the cultures of students' homes and communities, popular culture, and the changing worlds of work and the lives of young children (Gee, 2004; Heath, 1983; Knobel, 1999; Marsh, 2003). Given the potential negative effects of this disconnect on the ability of many students to learn and succeed within school, and on the possibilities available to them in the contemporary context of work, we need to focus more specifically on the language and literacy practices going on beyond the school walls in order to move past disconnection to meaningful use of those practices in ways that do not simply pedagogize them. Understanding how teachers can include a model of literacy that focuses on the literacy practices in use in everyday 
life leads us to look closely at the potential of out of school contexts for learning.

\section{Multiple Literacies and Moving Beyond School}

Moving beyond the school assists students' participation in culturally valued activities of their and others' communities and to the multiple literacy practices of everyday life. Students and teachers are then reading and writing the world, and themselves within this world, using the multiple literacies available across contexts. Drawing on a multiple literacies perspective, we can understand moving outside of school as not just an issue of nonformal versus formal learning, but as a practice in which the classroom walls are breached and students learn in more complex ways (Larson, 2005). Students participate in the multiple literacy practices of their own and others' communities at the same time that they participate in school-based literacy practices. Thus, students learn not just the literacy demands of education and schooling, but of life outside of school. Literacy practices that go beyond the classroom walls support students' capacity to authentically participate in a global information economy (Gee, 2004; Kress, 2003; Lankshear \& Knobel, 2003; Luke, 2003; Street, 2005).

For example, Gatto's field trips (e.g., the Urban Botany project and traveling to Kentucky through videoconferences and e-mail and literally by going there) build on the multiple literacies children bring from home, while also affording them the opportunity to experience multiple literacy practices in the contexts of their use that they may not have had access to in their everyday lives or in previous school experiences. ${ }^{1}$ These field trips were more than simply taking school outside; instead, students learned to cross communicative boundaries and the multiple literacies needed for full and democratic participation in a global information economy because they were able to participate in contemporary literacy practices (e.g., videoconferences, e-mail, Web site construction, scientific observation and documentation) that allowed full- er opportunities for authentic learning (Larson, 2005).

When we consider the nonclassroom-based dimensions of the multiple literacies used in this classroom, we find that students do not understand literacy to be restricted to any one place or time, but rather that multiple literacies occur in everyday activities in multiple contexts and at different times. In this way, they are developing and using multiple, complex literacies across local and global contexts as they move between and among diverse cultures and communities (Luke, 2003). The variation in learning spaces in the classroom described provided rich opportunities for fuller participation in both everyday community activities and school-based learning events. As a result, the division between inside and outside is blurred as literacy learning occurs across time and in multiple spaces (Leander, 2001). In sum, when the boundaries of the classroom are dissolved, the community becomes more than a place to visit, but is instead a context students participate in as authentic members of both local and global communities, or as participants in what Haraway (2003) refers to as "contexts of layered locals and globals" (p. 63). Building on the theme of moving outside the classroom, the next section outlines how multiple literacies can inform practices that teachers can use to work toward social justice and democracy in the larger societal context.

\section{Multiple Literacies for Social Justice and Participation in a Democratic Society}

Critical literacy serves as a useful framework for conceiving and implementing a multiple literacies curriculum that has an explicit goal of social justice and equitable participation in democratic societies. Historically grounded in critical social theory and critical pedagogy, critical literacy constantly challenges teachers and researchers to uncover implicit oppressions and transform them (Freire, 1972; Freire \& Macedo, 1987; Larson \& Marsh, 2005; Shor, 1980). While there is no singular definition of critical literacy, there is some consensus that a goal of critical literacy is to 
question the power relations in schooling and society that privilege some groups over others (Anderson \& Irvine, 1993)

A key emphasis in critical literacy in early childhood and elementary classrooms is the view of children as critical agents who bring insights on their world to the classroom and who do not first need to acquire a reductive set of print-based literacy skills and knowledge before they can engage in critical literacy practices inside and outside of school (Larson \& Marsh, 2005). To help connect critical literacy to pedagogy, Comber (2003, p. 276) suggests that critical literacy involves a number of key principles and repertoires for practice:

- Engaging with local realities,

- Researching and analyzing language-power relationships, practices and effects,

- Mobilizing students' knowledge and practices,

- (Re) designing texts with political and social intent and real-world use,

- Subverting taken-for-granted school texts,

- Focusing on students' use of local cultural texts, and

- Examining how power is exercised and by whom.

Using these principles, teachers and their students begin at different starting points for curriculum and pedagogy, points that redefine schoolbased literacy to emphasize local variations of global issues and seek to theorize "critical stories of young people and radical educators working for social justice" (Comber \& Simpson, 2001, p. 279). Vasquez (2004) describes her use of critical literacy to construct curricular and instructional spaces where young children could raise and act on social justice issues. She describes her practice of using what she calls an audit trail as one way for students to trace their thinking and their actions. Together, Vasquez and her students covered the classroom walls with artifacts and images (e.g., photographs, book covers, newspaper clippings, advertisements, transcripts of conversations) as a record of their journeys through their emerging sense of themselves as able to effect change in the world. The audit trail provided a tool for seeing and understanding where they had been and ideas for where they would go next.

Similarly, Gatto constructed instructional spaces, both inside and outside the classroom, where students' agency was an authentic part of everyday practice. One example of this is a project she did with a partner teacher in which they exchanged Habitat Boxes with seven schools in seven different states around the United States (Gatto \& Hart, 2000). Habitat Boxes contained 7-10 samples of objects that represented the different local habitats. Each class assembled identical boxes and sent them to one another. In Gatto's classroom, the students documented the entire process on one wall-sized bulletin board. They posted a map that highlighted all the states, their predictions about other habitats, objects from the boxes, e-mail and letter exchanges, and all artifacts of research. This board allowed them to rigorously document the process and their thoughts about it, and gave everyone (including parents and other visitors to the classroom) a visual way to compare objects and ideas across projects.

Practices such as those described positioned students and teachers in more symmetrical power relations through multiple literacies enacted in authentic curriculum, which in turn generated more authentic assessment practices. As the habitat project illustrates, Gatto purposefully realigned her position to be more symmetrical and as a result, she was able to assess student learning as an ongoing, everyday practice. The next section connects the practices described thus far with assessment strategies that take multiple literacies into account.

\section{Multiple Literacies and Assessment}

Literacy assessment is a value-laden, socially constructed, and historically situated practice. Underlying values about what counts as literacy, learning, and development fundamentally shape what counts as assessment and what form that assessment takes (Murphy, 2003). ${ }^{2}$ For example, Gatto (2001) and Vasquez (2004) both define literacy as multiple and complex practices in use, not as an autonomous set of neutral skills devoid of 
context. Given this different starting point, what counts as assessment changes. They would not consider standardized assessments of decontextualized skills adequate measures of what their students know and understand. They use multiple forms of assessment of a variety of forms or archetypes. Murphy (2003) argues there are three archetypes of assessment that are guided by distinct values and beliefs about childhood, literacy, and learning:

1. Standardized, large-group assessment in which definitions of literacies and measurable competencies are decided a priori;

2. Observation and documentary assessment where a priori definitions and competencies are considered in conjunction with observable behaviors and the physical environment;

3. Responsive-listening through which children's understanding is accessed and analyzed.

While standardized assessments are currently emphasized, all three of these perspectives may be familiar to experienced elementary teachers, as they have all appeared in a variety of forms over the years. Murphy's analysis articulates the mutually constituted relationship between values (ideologies/theoretical frameworks) and assessment and how assessment strategies change depending on what is valued, by whom, and for what purposes. Understanding these relationships between value systems may help teachers move around and between them toward more meaningful assessment practices.

How might a multiple literacies perspective inform and/or transform assessment in early childhood and elementary classrooms? Terms like $a u$ thentic assessment immediately come to mind, but what does authentic mean from a multiple literacies perspective? How can teachers use a multiple literacies perspective in the face of constant pressure for increased test scores on standardized assessments? This section articulates a possible theoretical stance (or set of values) of such a perspective and briefly describes some practices that might emerge.

A multiple literacies perspective locates literacy learning and its assessment not "in the head of the learner, but in the community in which it is practiced" (Murphy, 2003, p. 376; Rogoff, 2003). Learning as changing participation in culturally valued activity including school requires multiple routes to understanding what children know. Teachers are familiar with the concept of using assessment to inform instruction in such practices as running reading records (Clay, 1972a), miscue analysis (Goodman, 1973), and concepts about print (Clay, 1972b). While these practices have become increasingly standardized in the current testing environment, they are based in the observation archetype previously described and offer teachers one route to a deeper understanding of what children know.

Rogoff, Goodman-Turkanis, and Bartlett (2001) offer an example of how a multiple literacies perspective on assessment might be used. They conceived of assessment as evaluating children's progress rather than achievement in some finite sense. In their work, teachers and students participated in collaborative activity in which teachers observed what children did, when and how they needed help formulating ideas and putting them in writing, using multiple resources, and to get a sense of student engagement in activities presented. Using multiple data points in assessment of students' learning (e.g., teacher observations and reflections, student self-assessment, standardized tests, teacher constructed tests, conferences, written goal setting, and reflection) teachers can move beyond reductionist notions of achievement rooted in autonomous models of literacy toward authentic, practice-oriented understanding of what children $d o$ with literacy.

For Maier (Larson \& Maier, 2000) and Gatto (2001), assessment is an ongoing, integrated practice that helps them understand what their students are doing and what assistance they might need to accomplish their own learning goals. As I mentioned earlier, Maier gathers up her students' writing at several key points in the school year and carefully examines each piece to get an intimate sense of what her students are doing and with what they still need help. She designs her subsequent lessons based on this analysis. Gatto recently received Smartboard technology as part of being selected as the 2004 New York State Teacher of the 
Year. She and her students are learning the ins and outs of this technology together, designing and implementing activities as they emerge. Certainly Gatto takes a key leadership role in this process; however, students gain increasing responsibility as they learn. By participating with their students in literacy activities, both of these teachers were able to assess individual growth over time, understand how students' participation is transformed, and observe changes in responsibility for learning in ways that move beyond standardization. Shifting to a multiple literacies perspective affords teachers the opportunity to more fully understand, authentically use, and participate in the language and literacy practices children bring with them to the classroom.

\section{Conclusion}

In this article, I have discussed the implications of a multiple literacies perspective on curriculum, instruction, and assessment in early childhood and elementary classrooms. I located the discussion in examples of classroom practice to argue that when classrooms operate from a multiple literacies perspective, they can become contexts for learning where students' language and literacy practices count and where learning is mutually constituted in affinity spaces (Gee, 2004), spaces where who they are and can be is an explicit part of the agenda.

Furthermore, I argue that by shifting the focus of the teaching and learning of literacy from an autonomous model to include a multiple literacies perspective, we can construct authentic spaces for learning that prepare students for equitable participation in a global communication and information economy. Schools are in danger of becoming irrelevant-perhaps they already are-by ignoring the multiple literacies young children use in their everyday lives. Researchers and teachers need to see students' literacies as valuable curricular and pedagogical resources, and refocus literacy curricula to reflect current practices, but not in ways that reduce them to pedagogized outcomes (Lankshear \& Knobel, 2003; Street, 1995). Instead, schools need to be responsive to radically changing life pathways and to find ways to promote the teaching and learning of multiple literacies that are compelling for children (Gee, 2004).

\section{Notes}

1. Some examples of field trips include traveling to Boston and Kentucky, monthly walks to volunteer at a neighborhood nursing home, a year-long Urban Botanist project that required regular walks to the park, zoo sleepovers, and the typical trips to museums.

2. See Meisels \& Piker (2001) and Murphy (2003) for comprehensive reviews of assessment in early childhood.

\section{References}

Anderson, G., \& Irvine, P. D. (1993). Informing critical literacy with ethnography. In C. Lankshear \& P. McLaren (Eds.), Critical literacy: Politics, praxis, and the postmodern (pp. 81-104). Albany, NY: State University of New York Press.

Barton, D., \& Hamilton, M. (1998). Local literacies. London: Routledge.

Bloome, D., Carter, S., Christian, B., Otto, S., \& Shuart-Faris, N. (2005). Discourse analysis and the study of classroom language and literacy events: A microanalytic perspective. Mahwah, NJ: Lawrence Erlbaum Associates, Inc.

Clay, M. (1972a). The early detection of reading difficulties. Portsmouth, NH: Heinemann.

Clay, M. (1972b). Sand: The concepts about print test. Auckland, New Zealand: Heinemann.

Comber, B. (2003). Critical literacy in the early years: What does it look like? In N. Hall, J. Larson, \& J. Marsh (Eds.), Handbook of early childhood literacy (pp. 355-368). London: Sage.

Comber, B., \& Simpson, A. (Eds.). (2001). Negotiating critical literacies in classrooms. Mahwah, NJ: Lawrence Erlbaum Associates, Inc.

Dyson, A. (1993). Social worlds of children learning to write in an urban primary school. New York: Teachers College Press.

Dyson, A. H. (2002). Brothers and sisters learn to write: Popular literacies in childhood and school cultures. New York: Teachers College Press. 
Freire, P. (1972). Pedagogy of the oppressed (M. Bergman Ramos, Trans.). London: Sheed \& Ward.

Freire, P., \& Macedo, D. (1987). Literacy: Reading the word and the world. Westport, CT: Bergin \& Garvey.

Gatto, L. (2001). Success guaranteed literacy programs: I don't buy it! In J. Larson (Ed.), Literacy as snake oil: Beyond the quick fix (pp. 71-88). New York: Lang.

Gatto, L. A., \& Hart, R. S. (2000). Box up your habitat. Science and Children, 38(3), 18-23.

Gee, J. P. (2004). Situated language and learning: A critique of traditional schooling. New York: Routledge.

Goodman, K. (1973). Theoretical studies of patterns of miscues in oral reading performance. Washington, DC: U.S. Department of Health, Education, and Welfare, National Institute of Education.

Green, J., \& Harker, J. (Eds.). (1988). Multiple perspective analysis of classroom discourse. Norwood, NJ: Ablex.

Gutierrez, K., \& Rogoff, B. (2003). Cultural ways of learning: Individual traits or repertoires of practice. Educational Researcher, 32(5), 19-25.

Hall, N., Larson, J., \& Marsh, J. (2003). Handbook of early childhood literacy. London: Sage.

Haraway, D. (2003). The companion species manifesto: Dogs, people, and significant otherness. Chicago: Prickly Paradigm.

Heath, S. B. (1983). Ways with words. Cambridge, UK: Cambridge.

Irvine, P. D., \& Larson, J. (2001). Literacy packages in practice: Constructing academic disadvantage. In J. Larson (Ed.), Literacy as snake oil: Beyond the quick fix (pp. 45-70). New York: Lang.

Knobel, M. (1999). Everyday literacies: Students, discourse, and social practices. New York: Lang.

Kress, G. (1997). Before writing: Rethinking the paths to literacy. London: Routledge.

Kress, G. (2003). Literacy in the new media age. London: Routledge.

Lankshear, C., \& Knobel, C. (2003). New literacies: Changing knowledge and classroom learning. Buckingham, UK: Open University Press.

Larson, J. (2005). Breaching the classroom walls: Literacy learning across time and space in an elementary school in the United States. In B. Street (Ed.), Literacies across educational contexts: Mediating teaching and learning (pp. 84-101). Philadelphia: Caslon Press.

Larson, J., \& Gatto, L. (2004). Tactical underlife: Understanding students' perspectives. Journal of Early Childhood Literacy, 4(1), 11-41.
Larson, J., \& Maier, M. (2000). Co-authoring classroom texts: Shifting participant roles in writing activity. Research in the Teaching of English, 34(4), 468-498.

Larson, J., \& Marsh, J. (2005). Making literacy real: Theories and practices in learning and teaching. London: Sage.

Leander, K. (2001). "This is our freedom bus going home right now": Producing and hybridizing spacetime contexts in pedagogical discourse. Journal of Literacy Research, 33(4), 637-679.

Luke, A. (1994). The social construction of literacy in the primary school. Melbourne, Australia: Macmillan.

Luke, A. (2003). Literacy education for a new ethics of global community. Language Arts, 81(1), 20-22.

Marsh, J. (2003). One-way traffic? Connections between literacy practices at home and in the nursery. British Educational Research Journal, 29(3), 369-382.

Meisels, S. J., \& Piker, R. A. (2001). An analysis of early literacy assessments used for instruction. Ann Arbor, MI: University of Michigan School of Education, Center for the Improvement of Early Reading Assessment. Retrieved June 15, 2006, from http://www.ciera.org

Murphy, S. (2003). Finding literacy: A review of research on literacy assessment in early childhood. In N. Hall, J. Larson, \& J. Marsh (Eds.), Handbook of Early Childhood Literacy (pp. 369-378). London: Sage.

Ochs, E. (1988). Culture and language development: Language socialization and language acquisition in a Samoan village. Cambridge, UK: Cambridge University Press.

Rogoff, B. (2003). The cultural nature of human development. Oxford, UK: Oxford University Press.

Rogoff, B., Goodman-Turkanis, C., \& Bartlett, L. (2001). Learning together: Children and adults in a school community. Oxford, UK: Oxford University Press.

Shannon, P. (1992). Commercial reading materials, a technological ideology, and the deskilling of teachers. In P. Shannon (Ed.), Becoming political: Readings and writings in the politics of literacy education (pp. 182-207). Portsmouth, NH: Heinemann.

Shor, I. (1980). Critical teaching and everyday life. Boston: South End.

Street, B. (1995). Social literacies: Critical approaches to literacy in development, ethnography, and education. London: Longman. 
Street, B. (Ed.). (2005). Literacies across educational contexts: Mediating teaching and learning. Philadelphia: Caslon.
Vasquez, V. (2004). Negotiating critical literacies with young children. Mahwah, NJ: Lawrence Erlbaum Associates, Inc.

\section{TiP}

